Kazunobu Oyama, Professor, Doctor of Economics

Faculty of Economics, Kanagawa University, Japan

\title{
IDEALISM IS INCLINED TO REDUCE COMPLIANCE WITH LAW
}

\begin{abstract}
Summary
Idealism is inclined to create overly strict laws, rules, or standards. However, these excessively severe restrictions can be harmful to humankind. Therefore, laws that are too severe reduce compliance with the law. Low compliance with law causes serious accidents. In this study, I investigate Japanese leadership, which tends to avoid difficult discussions about correct standards based on scientific theory or data - Japanese leaders are easily influenced by public opinion or authority.
\end{abstract}

Keywords: idealism, compliance, panic phenomena, minus-bubble, excessively severe standard, Japanese leadership

\section{Introduction}

I hereby introduce three examples of overly severe laws or rules produced by idealism that are influenced by public opinion, without scientific data or theory. Firstly, I investigate a law concerned with radioactive level for refuge. Secondly, I look at the incident of the falsification of data by a Japanese production company. Thirdly, I examine the excessive obligation for university students by the Japanese government.

I conclude that Japanese management and leadership must change to control public opinion or its social atmosphere. Occasionally, Japanese management is admired by Occidental researchers. However, Japanese leaders do not resist the overall social atmosphere despite their professional knowledge and skill.

\section{Panic after the Fukushima nuclear accident}

The International Nuclear and Radiological Event Scale (INES) ranks the severity of damage of nuclear accidents from 1 to 7 . The accident at the Fukushima Daiichi Nuclear Plant in 2011 was categorized as level 7, as was the Chernobyl accident. The Japanese government at that time, led by Prime Minister Naoto Kan, was concerned with raising the INES level to a category $7 .{ }^{1}$

Jennex M. Using Social and Information Technologies for Disaster and Crisis Management. IGI Global, 2013. 
However, some nuclear specialists criticized the decision made by Kan's government. Mark Tran introduces a criticism from Murray Jennex, associate professor at San Diego State University².

In my opinion, raising [Fukushima] to the level of Chernobyl is excessive. It is nowhere near that level. Chernobyl was terrible - it blew up, and with no containment they were confounded, whereas [Fukushima] containment held, the only thing that did not was the fuel pool that caught fire.

Tran analysed the difference between the nuclear accidents of Fukushima and Chernobyl, comparing these nuclear crises through official data. For example, in the case of Chernobyl, the reactor itself exploded while it was still active. However, in the case of Fukushima, the cause of the accident was not the reactor itself but occurred because the plant's cooling system was impaired by a tsunami. ${ }^{3}$

Tran also pointed out the level of radioactive material released in each accident. Whereas the radioactive material released by Fukushima's plant reactors was estimated at more than $10 \mathrm{PBq}$ (petabecquerel) by the Japanese nuclear safety commission, the radioactive material released by the Chernobyl incident was estimated at $5200 \mathrm{PBq}^{4}$

Moreover, in the case of Chernobyl, Tran noted that 50 emergency rescue workers died from acute radiation syndrome and related illnesses. Furthermore, 4000 children and adolescents contracted thyroid cancer. ${ }^{5}$

In the case of Fukushima, however, no radiation-linked deaths have been reported and only 21 plant workers have been affected by minor radiation sickness. ${ }^{6}$

James Mahaffey has investigated various atomic accidents since the 1950 s. $^{7} \mathrm{He}$ also investigated the accident of Fukushima and Chernobyl in detail. He attributed the cause of the Fukushima accident to the 49-foot high tsunami that struck 50 minutes after a magnitude 7.2 earthquake (from the Great East Japan Earthquake),

2 Tran M. "Nuclear crises: How do Fukushima and Chernobyl compare?" The Guardian, April 12, 2011. He investigated the difference between the accident in Chernobyl and that in Fukushima. He pointed several important points of difference between them, notwithstanding the same category 7 of the INES level.

Other articles describe the difference between Chernobyl and Fukushima is included, as follows. Mahaffey J. Atomic Accidents. Pegasus Books, 2014; Brocato C. S. How A Nuclear Event In America Will Probably Go Down: What Was Learned From Three Mile Island, Chernobyl, and Fukushima. Dr. "B”s Radiation Series Book 6, 2018. Filburn T., and Bullard, S. Three Mile Island, Chernobyl, and Fukushima. Springer International Publishing, Switzerland, 2016. Claussen A, Rosen A. Nuclear Disasters: Fukushima and Chernobyl. Dixi Books Publishing, 2019.

3 Tran M. "Nuclear crises: How do Fukushima and Chernobyl compare?" The Guardian, April 12, 2011.

Ibid.

Ibid.

Ibid.

Mahaffey J. Atomic Accidents. Pegasus Books, New York, 2014. He also pointed out the important difference between the two nuclear accidents that happened in Chernobyl and Fukushima, just like as Tran, as I mentioned above. We can find that Japanese government and public opinion were led by overestimating the highest category 7 of the INES level to the panic reaction in nuclear management. 
which inundated the entire plant, while the cause of the Chernobyl accident was the nuclear reactor itself.

In 2011, just after the accident of the Fukushima nuclear plant, the government of Naoto Kan was apparently in a panic. ${ }^{8}$ They explained that the tsunami was of an exceptional scale and happened roughly once every hundred years. ${ }^{9}$ Despite this explanation, they decided to stop nearly all the nuclear plants in Japan, as if another exceptionally large wave was coming the next day. Their explanation of the accident, and certainly their political decision, lacked any scientific grounds. ${ }^{10}$

After the Fukushima accident, most Japanese people became afraid of nuclear power, and supported or agreed with the anti-nuclear movement. They created an anti-nuclear atmosphere, which Japanese leaders could not handle sufficiently well. I believe that this inclination of public opinion is the result of panic. ${ }^{11}$

This panic caused three main circumstances: uncertainty, involvement of a large number of amateurs, and the absence of reasonable investigation based on scientific knowledge.

Firstly, the uncertainty concerning nuclear energy and radioactivity among the general population and lack of knowledge or information stimulates uneasiness, anxiety, and fear. This emotional state in a large population causes panic.

Secondly, the involvement of a large number of amateurs. Including politicians, a large number of amateur commentators in the media - TV, radio, and newspapers - tried to explain the dangers of nuclear energy or the seriousness of the accident at the Fukushima Nuclear Power Plant having neither specialized knowledge nor honest investigation. Almost all of them denounced nuclear technology from an emotional standpoint.

In fact, after the Fukushima accident, many people bought Geiger counters, and measured the degree of the radioactivity around their homes. ${ }^{12}$ This craze proved that the anti-nuclear atmosphere had turned into a panic.

Furthermore, the Japanese government tried to search for active fault lines that are one million years old by digging the ground at each nuclear plant, spending several billions in yen, ${ }^{13}$ aside from the fact that the cause of the Fukushima accident had nothing to do with cracks in the ground but with being inundated by a tsunami.

8 The Independent Investigation Fukushima Nuclear Accident. The Fukushima Daiichi Nuclear Power Station Disaster: Investigating the Myth and Reality. Routledge, 2014.

9 Ibid.

10 The Independent Investigation Fukushima Nuclear Accident. The Fukushima Daiichi Nuclear Power Station Disaster: Investigating the Myth and Reality. Routledge, 2014.

11 産経新聞 Sankei Newspaper, 31 March 2013, 1 July 2013.

12 日本経済新聞 [Nihon Keizai]. Newspaper 8 May 2011. A column reported that demand for Geiger counters rose rapidly. After the Fukushima nuclear accident, a digital Geiger counter priced 98000 yen increased in demand 300 times.

13 原子力規制委員会 [2013 June]「敷地内及び周辺の地質·地質構造調査に係る審査力゙イ ド」[Guidance of Nuclear Regulation Authority. Guidance for geological investigation of nuclear plants and around them]. June, 2013. 
Such ridiculously formal activities by the government also proved the existence of panic and the lack of rational thinking.

\section{Japanese government set excessively severe standard in panic}

We see an atmosphere of unreasonable and emotional avoidance of nuclear technology in Japan after the Fukushima accident. According to Japanese cultural characteristics, such an atmosphere is inclined to dominate people. Therefore, the mass media usually tries to control the atmosphere.

Japanese leaders seldom debate any theme countering the prevailing opinion. For example, before the Fukushima accident, the leaders of Japanese electric companies rarely discussed the security of nuclear technology with anti-nuclear advocates. ${ }^{14}$ The leaders easily declared a $100 \%$ safety assessment to the public to avoid severe scientific debate. ${ }^{15}$ They managed to let the counterforce pass without controversy. This is characteristic of Japanese leadership.

However, their casual $100 \%$ safety declaration caused them to refrain from further improvement. Following the Fukushima accident, the same phenomenon reoccurs. Even today, Japanese leaders, including statesmen, the government, and corporate executives, avoid tough debates with anti-nuclear forces on the future policy of nuclear energy in Japan, just as before the Fukushima accident. Consequently, this Japanese traditional leadership style in coordinating a conflict resolution has serious limits.

Furthermore, another serious problem is that some Japanese leaders are inclined to submit to some dominant public opinions or atmosphere. However, many of these dominant opinions or atmosphere are easily created by the mass media. In the days of the Democratic Party government of Noda, after Kan, the Minister of Health, Labour and Welfare, Yoko Komiyama in October 2011 decided that the safe level of caesium radioactivity in food was less than $1 \mathrm{mSv}^{16}$, even though the international standard safety level is $5 \mathrm{mSv} .^{17}$

Likewise, the Minister of the Environment Goshi Hosono, who was a member of Noda's cabinet, was responsible for the governmental decision to set radioactivity levels for the evacuation zone. ${ }^{18} \mathrm{He}$ influenced the decision to set the acceptable radioactivity level for returning to the evacuation zone at $1 \mathrm{mSv}$, even though

14 Nakase T. 『日本電気事業経営史』第9章 [Business History of Japanese Electrical Industry. Chapter 9 日本評論社], 2005.

15 Ibid.

16 日本経済新聞 [Newspaper, Nihon Keizai Shinbun], October 28, 2011.

17 Terada, H. I. Yamaguchi, et al. Regulation values and current situation of radioactive materials in food『保健医療科学』[Medical Health Science], Vol. 67, No. 1, 2018, pp. 21-33.

18 内閣官房[Cabinet Secretariat's report]「低線量被ばくのリスク管理に関するワーキンググル ープ報告書」[Working Group's report for a risk management of low level radiation], December, 2011. 
the international standard was $20 \mathrm{mSv}^{19}$ In this decision-making process, local governments in Fukushima also held responsibility for the excessively severe standard, because they conformed to the $1 \mathrm{mSv}$ standard for the exhaustive cleaning of radio-activity to the national government. ${ }^{20}$ The leaders of the local governments in Fukushima also kowtowed to the dominant social opinion or atmosphere. ${ }^{21}$

In sum, these decisions were obviously a surrender to idealism of security. This excessively severe $1 \mathrm{mSv}$ standard for removing the evacuation zone designation is now hurting the refugees, towns, and villages in Fukushima. In 2012, more than 160000 persons took refuge from Fukushima. ${ }^{22}$ In 2018, some towns and villages in Fukushima were removed from the evacuation zone. ${ }^{23}$ However, a total of 3701 persons who had taken refuge from Fukushima were dead by September 30, 2018 due to various stressors or the lack of medical services in the refuges, a phenomenon called "deaths related to the Great East Japan Earthquake."24 Furthermore, many towns and villages forcibly emptied of inhabitants for an extended period of time have practically became ruins. ${ }^{25}$

Although the Liberal Democratic Party came to power after the Democratic Party at the end of 2012, no Minister of the Environment has ever tried to restore the level of refuge to $20 \mathrm{mSv}$ from $1 \mathrm{mSv}$. As they also bow to the idealism, such as maximum safety precedence, dominant social opinion, or anti-nuclear atmosphere, they hesitate to explain, discuss, or debate with the public using science-based knowledge and facts.

\section{The incident of data falsification by Japanese production company}

Traditionally, Japanese leadership has the characteristic of coordinating diversity of opinions. This style of leadership, however, is mainly concerned with the emotional conditions of its members. Certainly, this has the merit of keeping emotional harmony in an organization. However, this type of leadership also has the problem of avoiding disputation with others to find the truth or to realize some

19 内閣官房[Cabinet Secretariat's report]「低線量被ばくのリスク管理に関するワーキンググル 一プ報告書」[Working Group's report for a risk management of low level radiation], December, 2011.

20 Ibid.

21 福島県 [Fukushima government's report]. 「東日本大震災の記録と復興への歩み」[History of the great east Japan earthquake and reconstruction], 2013.

22 福島民友新聞 [Newspaper Fukushima Minyu Shinbun], September 8, 2017.

23 Ibid. March 12, 2018.

24 復興庁 [Reconstruction Agency's Report].「東日本大震災における震災関連死の死者数」 [Number of the great east Japan earthquake-related deaths], September 30, 2018.

25 Aoki, M. 『地図から消される街-「3.11後の言ってはいけない真実」-』講談社新書 [Disappering towns. The taboo truth after 3.11], 2018. The author reported the cases of the damage suffered by refugees, and several towns and villages were falling into ruins after the long refuge caused by the overly strict removing standard $1 \mathrm{mSv}$. 
important objectives. In particular, Japanese leaders are inclined to be submissive to or flatter some dominant opinions to avoid difficult discussions, as I have mentioned. This is a serious fault of Japanese leadership.

In the future, Japanese leaders in any organization must be sufficiently brave to enter into a debate with anyone about any topic in an attempt to establish the truth in the best interest of public welfare. In any discussion or disputation, scientific bases or facts are important. Japanese leaders must utilize science-based data or knowledge to persuade opponents without resorting to emotion.

Recently, many incidents of data falsification by Japanese production companies have been reported. For example, Kobe Steel is a famous and large company that had falsified data on its steel material for more than 40 years. ${ }^{26}$ They adopted a special standard that they themselves set for a test of the material products. ${ }^{27}$ This standard is called tokusai, an abbreviation of tokubetsu saiyo, which means "special adoption".

Of course, this tokusai standard is lower than the regular standard. However, many client enterprises acknowledge the tokusai standard, and accepted the products that passed the tokusai standard. ${ }^{28}$ What should we learn from this incident? A spirit of compliance to appear to be legitimate is important, evidently. However, I would like to rase two points. First of all, no accidents have ever been caused by this lower tokusai standard. Secondly, the client enterprises agreed with the tokusai standard.

To summarize, the most important problem is whether the regular standard was excessively severe. If the regular standard was set too high to produce quality products at suitable costs and within an appropriate period of time, the regular standard cannot be a legitimate standard. We must remember that an excessively severe level for removing the evacuation zone ban is harming both the refugees and the area around Fukushima.

These excessive or idealised standards are often created by overly dominant opinions or atmospheres lacking scientific discussion. They assert that Japanese people usually use this stated principle and true intention appropriately. I think the core problem of these types of incidents is the lack of scientific discussion by Japanese leaders. In other words, the lack of bravery of Japanese leaders, preventing them from entering tough disputations against powerful opponents is the core problem.

26 毎日新聞 [Newspaper Mainichi Shinbun], 17 October, 2017.

27 Ibid.

28 Aluminum \& Copper Business: Moka Plant, Kobelco Material Copper Tube, LTD, etc. actually reported, "With respect to internal standards that are overly strict, we will review shipping decisions based on internal standards and undertake correction action by unifying shipping decisions based on customer standards." "Report on investigation into the cases of the Kobe Steel Group's improper conducts and on measures to prevent recurrence." Kobe Steel Ltd., 2017. 


\section{Excessive obligations for university students}

I would like to introduce another case of a Japanese university that was concerned with creating an excessively severe standard as an example of the Japanese decision-making process.

In 2018, the Ministry of Education, Culture, Sports, Science and Technology Japan (MEXT) decided that every student must prepare notes for two hours, and spend two hours in review for every subject they take. The university's office formally demanded that every professor must record this obligation for students in their syllabus. ${ }^{29}$

As a student impacted by this rule, I argued with a clerk who demanded compliance. I insisted that four hours of preparation and review for each subject that a student took was impossible. No professor should publish such an unrealistic obligation for students in the syllabus. However, the clerk insisted that this policy was decided by official committees in our university, guided by MEXT. ${ }^{30}$

Then, I explained to the clerk what it meant. Most students take about 12 classes a semester. If they must study for four hours for each class, they must study for 48 hours a week in total. It means that every student must study for about seven hours a day, seven days a week. Yet, after attending classes at the university, students may go home, eat dinner, and shower before they start their studies at 8 p.m., and they must not stop studying until 3 a.m. They must keep this schedule every day. Consequently, this precludes any students' activities, part-time work, and social activity.

I informed the dean of our faculty that this unreasonable policy had to be reconsidered. He accepted my proposition immediately. However, it will take a long time to abolish this institutionalized policy. Furthermore, most of the professors accepted the requirement by the university as the authorities intended. Therefore, the obligation for students will continue to be published on official syllabuses for a long time. I think that this type of decision is closely related to the falsification problems of Japanese enterprises.

Through the analysis mentioned above, we can summarize the Japanese leadership style and decision-making approach, as follows. Firstly, Japanese leaders usually do not like debating with people over issues. They would like to coordinate conflicting opinions rather than prevail against opposing opinion or persuade an adversary.

Secondly, leaders are inclined to be submissive to a dominant atmosphere or an authority. Then they wait patiently for objections to subside. This tolerance is useful to avoid a severe conflict, at least for a while; in fact, many radical objections in Japan decline or disappear during this tolerant, submissive period.

29 Professors' meeting at Kanagawa University, November 2018.

30 We can find an idealistic policy of the Japanese Ministry of Education, Culture, Sports, Science and Technology on a White Paper of the Ministry and in internet data. Available at: https://elaws.e-gov. go.jp/ search/elawsSearch/elaws_search/lsg0500/detail?lawId=331M50000080028 [last viewed April 5, 2020]. 
Thirdly, Japanese leaders are inclined to be concerned with emotional conditions rather than rational or scientific affairs. Of course, this tendency of Japanese leadership is related to the characteristics of Japanese society. Japanese society holds the opinion that the critical element of leadership is humanity rather than ability.

\section{How must the Japanese leadership style be changed to overcome the excessive demands based on idealism?}

According to the characteristics of Japanese leadership style, although they have a merit for avoiding severe conflicts between opponents and realizing appropriate agreements in adequate time after long negotiations, their downside is the tendency to be swayed by idealism, populism, or emotionalism with comparative ease.

We must remember the causes of panic phenomena as described in the previous section. Fundamentally, panic is mainly caused by irrational and emotional enthusiasm in the public under the conditions of uncertainty. The illogical, excessive hope and expectations of the majority causes the euphoria of a plus-bubble, while a minus-bubble is caused by the majority's irrational excessive anxiety and fear. Both are panic phenomena.

I see Japanese public opinion as a factor in the phenomenon of the minusbubble after the Fukushima accident. Actually, this minus-bubble phenomenon has expanded to some foreign countries. For example, the German government decided to stop nuclear energy development after the Fukushima accident.

I do not know if the Japanese leadership is effective enough to solve this type of problem as a kind of panic phenomenon, as Japanese leadership is weak in the face of emotional public opinion, and the panic phenomenon is formed by public emotion.

Let us review the problems of creating excessively severe standards for radioactivity by the Democratic Party, the numerous incidents of data falsification by Japanese production companies caused by creating excessively high standards, and establishment of excessively stringent study obligations for students at Japanese universities.

Why do Japanese leaders create such unrealistic standards? The excessive standard is usually the result of pandering by Japanese leaders to some dominant influence, such as public opinion or authority. Particularly in the case of a dominant influence based on idealism, Japanese leaders are apt to easily accept any demand posed by the dominant influence.

"As the human security is the most important factor, a severe standard for radio-activity is the best approach," "Since higher quality products are the most important factor for customers, a higher quality standard is the best approach," "As training students is the mission of each university and each professor, a higher study standard is the best approach., ${ }^{31}$ Because these types of substantiation are based on

31 These advocacies are the examples reflecting idealism in each field. 
idealism, any responsible person of any organization feels a difficulty in disputing or opposing them.

Other types of advocacy, such as peace, democracy, equality, and so on, also have an irresistible power for the majority. In general, Japanese leadership is weak in disputing such kinds of advocacy based on idealism. Of course, Japanese leaders in any organization sometimes must resist or fight against unreasonable claims. However, even in that case, they usually adopt the Japanese style of leadership, avoiding much dispute.

In the case of nuclear policy, the Japanese style of leadership has several fatally weak points. First of all, this approach takes a long time to persuade an opposing influence. As I mentioned in section 2 above, a large number of refugees have been sacrificed during the attempt to reach a consensus on restoring the safe radioactivity level in evacuation zones to $20 \mathrm{mSv}$ instead of $1 \mathrm{mSv}$.

Secondly, the opposing influence will never be persuaded by a long and patient negotiation, because of their political conviction against nuclear development in Japan.

Thirdly, an emotional approach to solving the problem of the nuclear accident will produce a contrary effect. For example, if the government emotionally talked about the large number of sacrificed refugees or the devastated villages in Fukushima where refugees could not return as a means of promoting the restoration of the radioactivity level in evacuation zones to $20 \mathrm{mSv}$ from $1 \mathrm{mSv}$, that appeal would be utilized by opposing actors to promote anti-nuclear development.

To overcome the idealism, Japanese leadership must become more aggressive in basing its policies on scientific logic against an illogical, emotional atmosphere. As I mentioned above, the panic phenomenon of minus-bubble is constructed by unreasonable fears, uncertainties, and anxieties in the majority population. Therefore, leaders of any organization must communicate precise information and explain logical theory, assisted by specialists.

\section{Conclusions}

In this article, I proposed the idea that scientific data, knowledge, and feasibility are important to create laws in our society. However, idealism is inclined to serve as a basis for establishing overly strict laws and rules. I introduced three cases, in which excessively strict standards harm actual human life and reduce compliance with the law.

The first case is the overly severe radioactivity standard. The Japanese government set an excessively severe standard of $1 \mathrm{mSv}$ as an acceptable radioactivity level for returning to an evacuation zone in a panicked reaction after the Fukushima nuclear accident in 2011, even though the international standard was $20 \mathrm{mSv}$. This decision was a surrender to the idealism of perfect security. However, this excessively severe standard caused the deaths of 2250 people due to the lack of medical services or because of various other stressors during the extended period of refuge. 
The second case is the falsification of data by Kobe Steel in Japan. Shop workers created their own standard called tokusai because of the excessively severe formal standard. This tokusai standard had been adopted for 40 years, not only by the shop workers but also by client companies. While there are currently no reports of accidents due to the tokusai standard, this reduction in compliance with the rule may cause serious accidents in future. Therefore, adequate regular standards are necessary to maintain compliance.

The third example is the excessively severe obligation for university students established by Japanese government in 2018. The new rule, which imposes upon students an obligation to study - preparing for class and reviewing their lecture notes for about seven hours every day, is never feasible. This rule may reduce students' compliance with other rules at the university.

Furthermore, I mentioned that a characteristic of Japanese leadership is inclined to be submissive to the dominant atmosphere or to idealism. However, to comply with the law, when we enact laws, rules, or standards, we must consider scientific data, knowledge, and feasibility instead of an emotional atmosphere and idealism. In any case, we should have the courage to debate with positions adopted in spirit of unrealistic idealism to safeguard compliance with laws.

\section{BIBLIOGRAPHY}

\section{Literature}

1. Ahn J., Carson C., Jensen M., Juraku K., Nagasaki S., Tanaka S. Reflections on the Fukushima Daiichi Nuclear Accident: Toward Social-Scientific Literacy and Engineering Resilience. Springer, 2014.

2. Aluminum \& Copper Business: Moka Plant, Kobelco Material Copper Tube, LTD, 2017.

3. Amidon Lusted M. The Chernobyl Disaster. Essential Library, 2011.

4. Aoki M. 『地図から消される街-「3.11後の言ってはいけない真実」-』講談社新書 [Disappearing Towns. The taboo truth after 3.11.] Kodansha shinsho, 2018.

5. Atomic Energy Society of Japan. The Fukushima Daiichi Nuclear Accident. Final Report of the AESJ Investigation Committee. Springer, 2016.

6. Brocato C. S. How A Nuclear Event In America Will Probably Go Down: What We Learned From Three Mile Island, Chernobyl, and Fukushima. Dr. "B”s Radiation Series, Book 6, 2018.

7. Burgan M. Chernobyl Explosion Compass. Point Books, 2018.

8. Burlakova E. B., Naidich V. I. 20 Years After the Chernobyl Accident: Past, Present and Future. Nova Science Pub. Inc. 2006.

9. Ferguson C. D., Jansson M. Regulating Japanese Nuclear Power in the Wake of the Fukushima Daiichi Accident. Federation of American Scientists, 2013.

10. Charles, River Editors. The Chernobyl Disaster: The History and Legacy of the World's Worst Nuclear Meltdown. Charles River Editors, 2014.

11. Claussen A., Rosen A. Nuclear Disasters: Fukushima and Chernobyl. Dixi Books Publishing, 2019.

12. Dowswell P. The Chernobyl Disaster: April 26, 1986. Heinemann/Raintree, 2003.

13. Marples D. R. The Social Impact of the Chernobyl Disaster. Palgrave Macmillan, 1988. 
14. Filburn T., Bullard S. Three Mile Island, Chernobyl, and Fukushima. Springer International Publishing, Switzerland, 2016.

15. 福島県 [Fukushima government’s report].「東日本大震災の記録と復興への歩み」 [History of the great east Japan earthquake and reconstruction], 2013.

16. 復興庁 [Reconstruction Agency's Report].「東日本大震災における震災関連死の死者 数」[Number of the great east Japan earthquake-related deaths], September 30, 2018.

17. 原子力規制委員会 [Guidance of Nuclear Regulation Authority 2013 June]. 「敷地内及び 周辺の地質・地質構造調査に係る審査ガイド」[Guidance for geological investigation of nuclear plants and around them], June, 2013.

18. Hindmarsh R. Nuclear Disaster at Fukushima Daiichi: Social, Political and Environmental Issues. Routledge, 2013.

19. Imazawa Makoto.『日産、神戸製鋼は何を間違えたのか』[Nissan and Kobe Steel Company, what mistake did they make?]. 毎日新聞出版. Mainichi Shinbun Press, 2018.

20. Ingram S. W. The Chernobyl Nuclear Disaster. Facts on File, 2005.

21. Jennex M. Using Social and Information Technologies for Disaster and Crisis Management. IGI Global, 2013

22. Kadota Ryusho.『死の淵を見た男 吉田昌郎と福島第一原発の五○○日』[A Man who looked the depth of death- Yoshida Masao and 500 days of the First Plant of the Fukushima Nuclear Generation PHP]. 研究所, 2012.

23. Kobe Steel, Ltd. Report on the Kobe Steel Group's misconduct. March 6, 2018.

24. Kobe Steel, Ltd. Report on investigation into the cases of Kobe Steel Group's improper conducts and on measures to prevent recurrence. November 10, 2017.

25. Kunihiro Tadashi. [『企業不祥事を防ぐ』Protection from Companies'Scandals]. 日本経済新 聞出版社. Nihonkeizai Newspaper Press, 2019.

26. Lochbaum D., Lyman E., Stranahan S. Q. The Union of Concerned Scientists Fukushima: The Story of a Nuclear Disaster. The New Press, 2015.

27 Mahaffey J. Atomic Accidents. Pegasus Books, New York, 2014.

28. Mara Wil. The Chernobyl Disaster: Legacy and Impact on the Future of Nuclear Energy. Benchmark Books, 2010.

29. 内閣官房 [Cabinet Secretariat's report].「低線量被ばくのリスク管理に関するワーキン ググループ報告書」. Working Group's report for a risk management of low level radiation, December, 2011.

30. Nakase Tetsushi. [『日本電気事業経営史』Business Management History of Japanese Electrical Industry] 日本評論社. Nihon Hyoronsha, 2005.

31. Nakata K. H. Sugisaki. Impacts of the Fukushima Nuclear Accident on Fish and Fishing Grounds. Springer, 2015

32. National Academy of Sciences. Lessons Learned from the Fukushima Nuclear Accident for Improving Safety and Security of U.S. Nuclear Plants: Phase 2, 2016.

33. Nelson D. E. Chernobyl (Perspectives on Modern World History). Greenhaven Press, 2009.

34. OECD Nuclear Energy Agency. Five Years After the Fukushima Daiichi Accident: Nuclear Safety Improvements and Lessons Learnt. OECD, 2016.

35. Peterson M. The Chernobyl Disaster. Nova Science Pub. Inc., 2016.

36. Rissman R. The Chernobyl Disaster (History's Greatest Disasters). Core Library, 2013.

37. Shestopalov V. M. Chernobyl Disaster and Groundwater. CRC Press, 2002. 
38. Takahashi S. Radiation Monitoring and Dose Estimation of the Fukushima Nuclear Accident. Springer, 2014.

39. Terada H., Yamaguchi I. et al. Regulation values and current situation of radioactive materials in food. 『保健医療科学』[Medical Health Science], Vol. 67, No. 1, pp. 21-33.

40. The Independent Investigation Fukushima Nuclear Accident. The Fukushima Daiichi Nuclear Power Station Disaster: Investigating the Myth and Reality. Routledge, 2014.

41. Nakanish T. M., O 'Brien M., Tanoi K. Agricultural Implications of the Fukushima Nuclear Accident (III): After 7 Years. Springer, 2019.

42. Tona N. 『企業不祥事と日本的経営一品質と働き方のダイナミズム一』晃洋書房 [Companies' Scandals and Japanese Management - Dynamism between Quality and Working Style]. Koyoshobo, 2019.

43. Tran M. Nuclear crises: How do Fukushima and Chernobyl compare? The Guardian, April 12, 2011.

44. Yasuoka T.『企業不正の研究 リスクマネジメントがなぜ機能しないのか?』 日経 [Investigation of Companies' Injustice, Why Risk Management Do Not Work?]. Nikkei, BP, 2018.

45. Yotaro H., Seiji A., Masao F., Naoto K., \& Kenji I. The 2011 Fukushima Nuclear Power Plant Accident: How and Why Did It Happen? Woodhead Publishing, 2014.

46. White Paper on Ministry of Education, Culture, Sports, Science and Technology, 2017.

47. 大学設置基準 [The standard for creating universities], 2019. Available at: https://elaws. e-gov.go.jp/search/elawsSearch/elaws_search/lsg0500/detail?lawId=331M50000080028 [last viewed April 4, 2020]. 